\title{
Migration of Yellowtail in Relation to Intrusions of Warm Water from the Kuroshio
}

\author{
Shingo Kimura, Akihide Kasai, ${ }^{\dagger}$ and Takashige Sugimoto \\ Ocean Research Institute, University of Tokyo, Minamidai, Nakano, Tokyo 164, Japan \\ (Received August 23, 1993)
}

\begin{abstract}
In the Kumano-nada and Enshu-nada Seas, warm water masses from the Kuroshio intrude into the coastal area depending on the paths type of the Kuroshio. Associated with the intrusions which occur with a period of 50 days from the Izu Peninsula when the Kuroshio takes the B-type path, yellowtail adults called buri migrate to the coastal area. However, the long time-lag between the intrusion and buri catch causes a negative relationship between the temperature and catch. The results suggest that the buri school migrates westward after the water mass has diffused. Since there is a positive relathionship between temperature and catch associated with very rapid intrusions when the Kuroshio takes the C-type path, it is necessary to distinguish oceanographic phenomena in order to understand the fish behavior in response to offshore oceanic changes. In addition, the seasonal horizontal temperature gradient should be considered when estimating the optimum temperature range for fish because the relative temperature change greatly affects fish migration rather than the optimum temperature.
\end{abstract}

Key words: Kuroshio, yellowtail, migration, eddy, meander

Historical analyses of fishing conditions in the Kuroshio region have focused on large-scale fluctuations of the path of the Kuroshio. ${ }^{1-6)}$ These analyses indicate that large fish catches should be expected in the coastal area when the Kuroshio approaches the coast and conclude that the density of fish between the Kuroshio and the coast is an important factor which controls fish catches in the coastal area. However, fish behaviors are not always subject to such large-scale fluctuations of the Kuroshio's path, short periodic fluctuations in the path cause warm water intrusions to the coast and these have a rather large effect on the fishing conditions in the coastal area of the Kumano-nada Sea. ${ }^{7-10)}$

When the Kuroshio does not meander greatly, the path follows a very stable route to the west of the Kii Peninsula and large fluctuations are restricted to the east of the Kii Peninsula. ${ }^{11,12)}$ In particular, warm water masses derived from the Kuroshio often intrude into the coastal areas of the Kumano-nada and Enshu-nada Seas locaged to the east of the Kii Penninsula. They move northeastward from the south of Cape Shionomisaki along the Kii Peninsula ${ }^{7,13,14}$ ) and westward from the south of Izu Peninsula along the coast of the Enshu-nada Sea. ${ }^{15-18)}$ The intrusions occur with about a 20-day period in the seas caused by small-scale changes in the Kuroshio's path ${ }^{7,17-19)}$ and with a 50-day period in an " $\mathrm{s}$ " shape meandering of these intrusions play an important role not only in the water mass and energy exchanges between the open ocean and the continental shelf region ${ }^{20)}$ but affect fish migration.

It is well known that matured adult yellowtail (Seriola quinqueradiata) called "buri" in Japanese migrate in large numbers northward to feed and southward to spawn in the Pacific Ocean. ${ }^{2122)}$ The warm water intrusion from the Kuroshio influences the migration route and leads to large catches of buri in the Kumano-nada Sea. ${ }^{8,10,23)}$ This paper therefore discusses the characteristic behavior of buri in relation to the warm water intrusions from the Kuroshio and fluctuations in the coastal water temperature, and the optimum temperature range for buri. ${ }^{24)}$

\section{Materials and Observations}

In the coastal area of the Kumano-nada Sea, the sea surface temperature (coastal SST) is measured once a day through the set net fishing season (October-July). The eighteen permanent set net stations in Mie Prefecture are shown in Fig. 1. At these set net stations, adult yellowtail migrating southward are usually caught during the fishing season. The temperature and catch data of yellowtail during the 1985-1988 fishing season published in Statistics of Buri Catch at Set Net Stations in Mie Prefecture ${ }^{25-281}$ were used in this analysis. Since one fishing season extends over two years, the years quoted in this paper refer to the period from October to the following

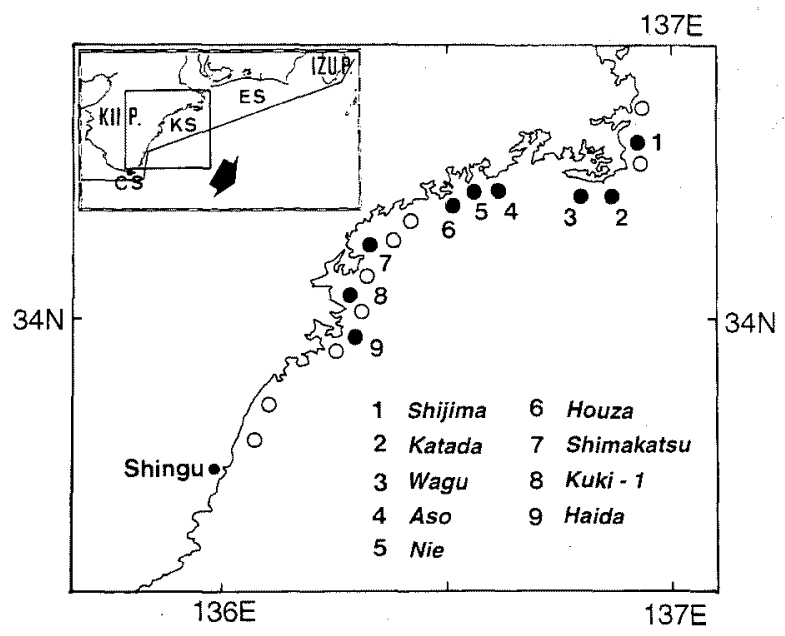

Fig. 1. Location of set net stations in Mie Prefecture and cruise line of the Sunflower 8.

Solid and open circles indicate set net stations used for time series analysis for temperature and other stations, respectively. KS, ES, and CS denote the Kumano-nada Sea, Enshu-nada Sea and Cape Shinomisaki, respectively. 

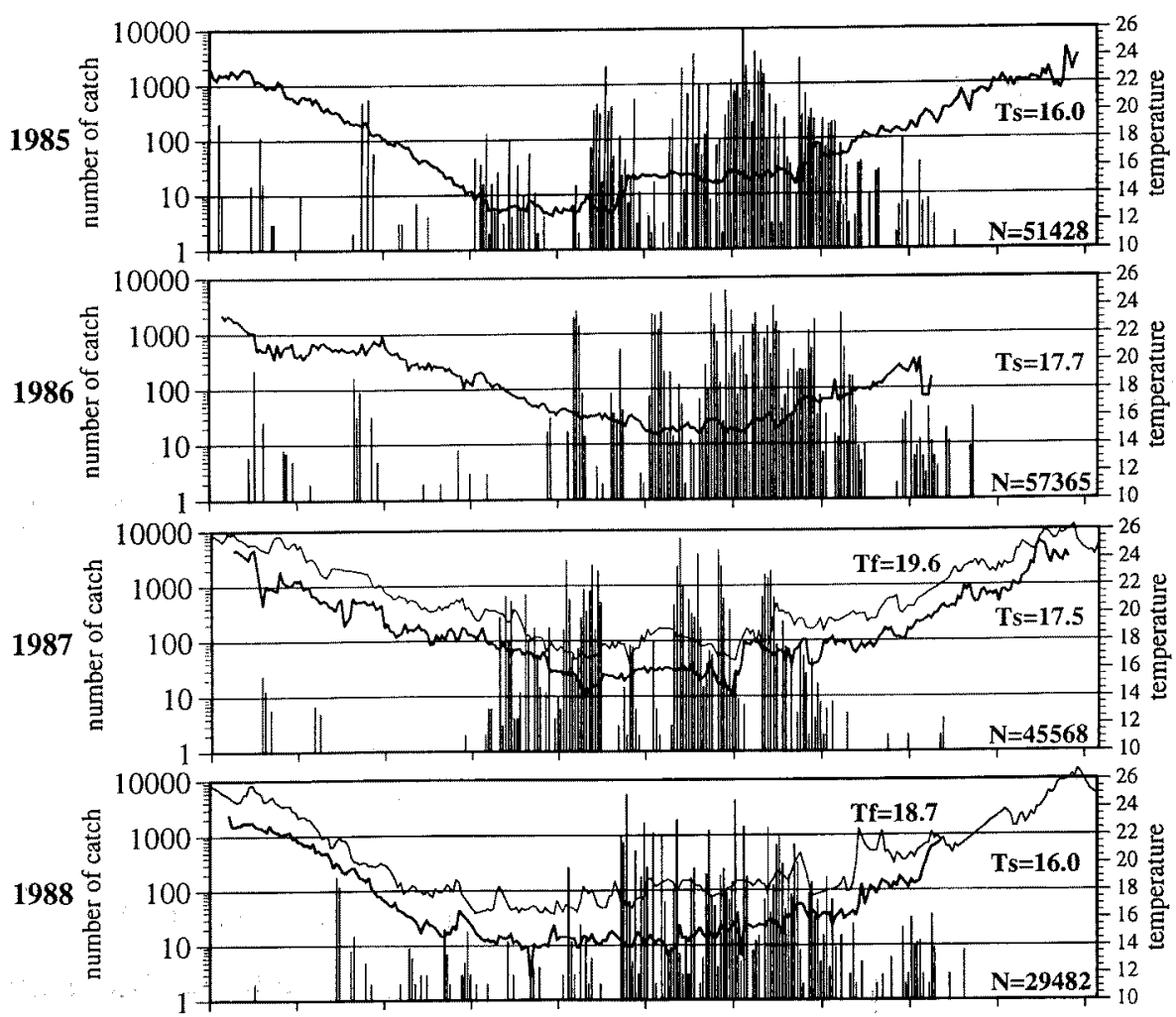

Oct. Nov. Dec. Jan. Feb. Mar. Apr. May Jun. Jul.

Fig. 2. Variation of average temperature at set net stations in Mie Prefecture (bold lines), total catch of buri (adult yellowtail) at the set net stations (bars), and average temperature measured by the ferry boat between $136.5^{\circ} \mathrm{E}$ and $137^{\circ} \mathrm{E}$ (thin lines) during $1985-1988$ fishing year.

Ts and $\mathrm{T} f$ indicate average temperatures measured at the set net stations and by the ferry boat, respectively.

$\mathrm{N}$ indicates the total catch of buri.

July. In the statistics, yellowtail are classified by weight into three classes buri (more than $6 \mathrm{~kg}$, adult yellowtail), warasa (more than $2 \mathrm{~kg}$ ), and inada (more than $0.5 \mathrm{~kg}$ ) and the classified names are used in this paper. For time series analysis, several temperature data were excluded due to lack of adequate measurements.

The sea surface temperature in the offshore area (offshore SST) is monitored by a ferry boat, the Sunflower 8 , (presently the Sunflower Tosa) which shuttles between Tokyo and Kouchi via Shinsu for two days. The feery boat cruises in a straight line between $136^{\circ} \mathrm{E}$ and $139^{\circ} \mathrm{E}$ as shown in Fig. 1. The temperature is measured every five minutes by a sensor in the intake pipe for cooling the engines. The temperature for a particular geographic location is determined from data on the ship's location and time lapse monitored by a Loran-C receiver (system is now equipped with a Global Positioning System).

\section{Results}

Figure 2 shows the time sequences of average coastal SST at the set net stations, total catch of buri, and average offshore SST between $136.5^{\circ} \mathrm{E}$ and $137^{\circ} \mathrm{E}$ observed by the ferry boat. The large southward spawning migration of fish schools through the coastal area of the Kumano-nada Sea started in early January in 1985 and 1987, but in 1986 and 1988 started in February. The migration ended in early June in 1985, 1986, and 1988, but in early May in 1987. During the four years, the total catch fluctuated from 30 to 60 thousand with an average of 45 thousand. This variation is usual in the last two decades according to Statistics of Buri Catch at Set Net Station in Mie Prefecture. ${ }^{28)}$ Comparing the catch in 1986 with that in 1988, the start and end of the migration occur at the same time, yet the

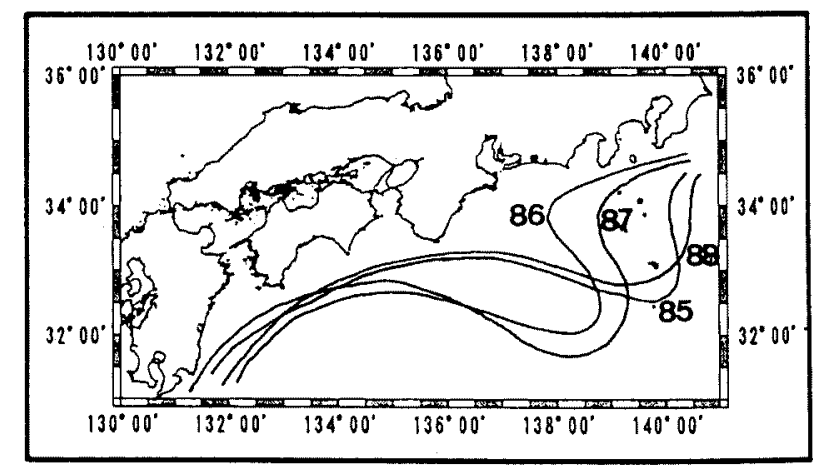

Fig. 3. Year-averaged paths of the Kuroshio. Numerals are the years.

total catch is quite different. This indicates that the time and period of migration to the coast are not related to the total catch. Thefefore, since the total number of fishing days in each year are almost the same, the effects of difference of fishing effort on catch seem to be quite small.

The coastal SST in 1985 and 1988 declined more rapidly from October to January than in 1986 and 1987. The average coastal SST in 1986 and 1987 were $17.7^{\circ} \mathrm{C}$ and $17.5^{\circ} \mathrm{C}$, respectively, whereas in 1985 and 1988 were both $16.0^{\circ} \mathrm{C}$ which is about $2^{\circ} \mathrm{C}$ less than in 1986 and 1987 . The variations in offshore SST are similar to those in coastal SST. Although the average offshore SST is only $1-2^{\circ} \mathrm{C}$ higher than the 
coastal value, the two temperature lines do not intersect even if sudden changes in offshore SST are observed. This suggests that the offshore water mass does not intrude directly to the coastal area. During the four years, the Kuroshio changed its path every year. Figure 3 shows the average path of the Kuroshio in each year corresponding to the yellowtail fishing season. The paths were estimated from contours of $15^{\circ} \mathrm{C}$ at a depth of $200 \mathrm{~m}$ from data of the Hydrographic Department, Maritime Safety Agency of Japan. The Kuroshio took a path with a small meander west of the Izu Ridge in 1986 and 1987, called the B-type path, while the path with a small meander on the Izu Ridge in 1985 and 1988 is called the C-type path. When the Kuroshio takes the B-type path, the warm water mass separated from the Kuroshio intrudes into the Enshu-nada Sea from the south of the Izu Peninsula and supplies a large amount of heat energy to the coastal area. ${ }^{7,18,20)}$ This phenomenon is also seen when the Kuroshio takes a large meander path (A-type path) which is similar to the B-type path but has a very large amplitude of meander. ${ }^{29)}$ Therefore, the high water temperature and its slow decline observed in the coastal and offshore areas can be attributed to the intrusion of warm water from the Kuroshio.

In 1987, large warm water intrusions from the south of the Izu Peninsula occurred three times in December, February, and April. Figure 4 shows a time-space diagram of offshore SST with seasonal variations removed and the numbers of buri caught in the three areas. Seasonal variations are removed by subtracting the two months running mean value from the raw SST data. The classification is based on the cross-correlation coefficients of observed temperatures at the set net stations indicated by solid circles in Fig. 1 and the results are shown in Table 1. Since several set net stations do not take sufficient

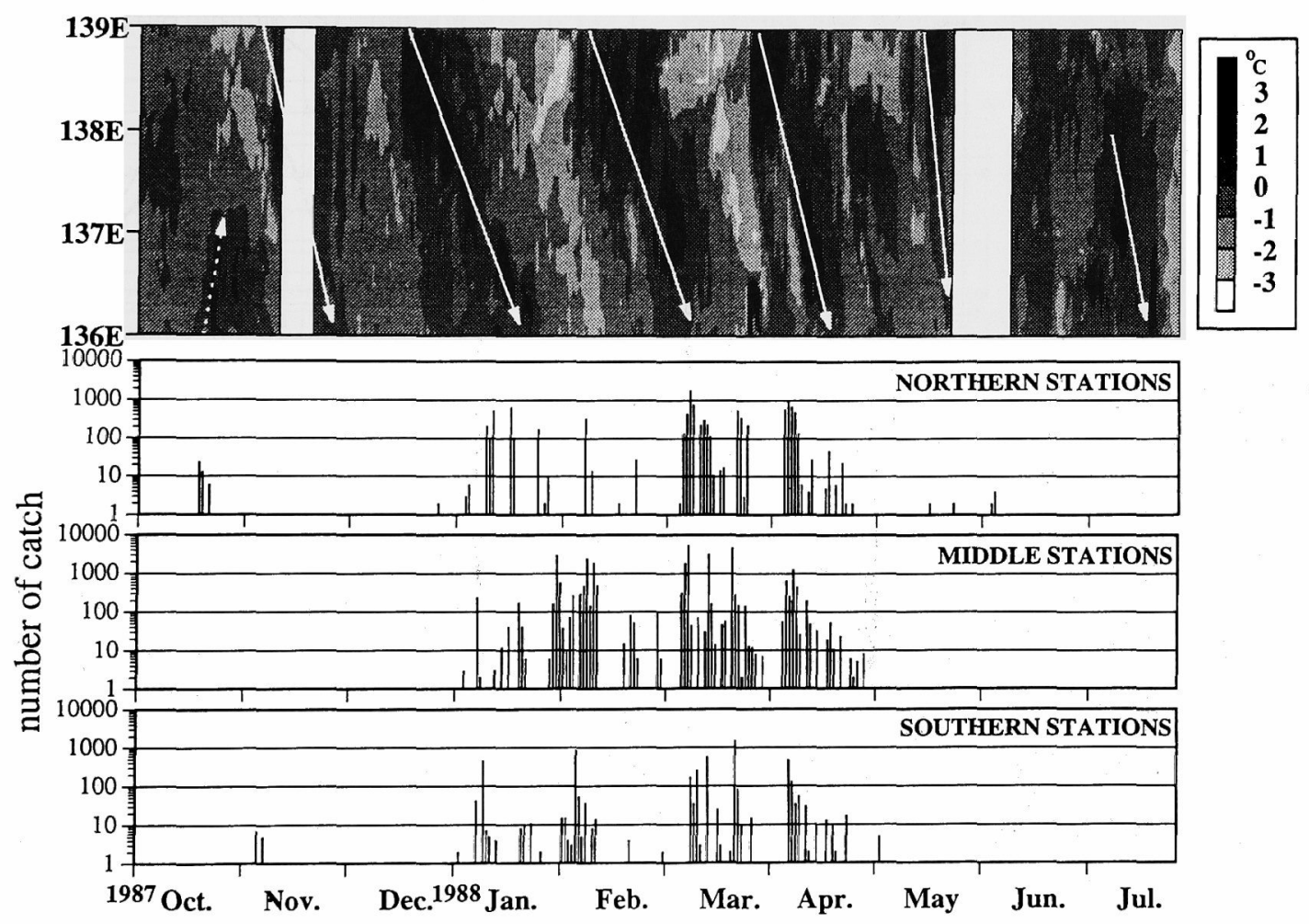

Fig. 4. Time-space diagram of sea surface temperature measured by the ferry boat and variation of buri catch in the northern ( 5 stations), middle (9 stations), and southern (4 stations) areas in 1987.

Solid and broken arrows indicate intrusions from east to west and from west to east, respectively.

Table 1. Cross-correlation coefficients among temperatures at set net stations in 1987

\begin{tabular}{|c|c|c|c|c|c|c|c|c|}
\hline & SHIJIMA & KATADA & WAGU & ASO & NIE & HOUZA & SHIMAKA & KUKI-1 \\
\hline KATADA & $0(0.70)$ & & & & & & & \\
\hline WAGU & $0(0.72)$ & $0(0.75)$ & & & & & & \\
\hline ASO & $+1(0.56)$ & $+1(0.61)$ & $+1(0.59)$ & & & & & \\
\hline NIE & $+2(0.45)$ & $+2(0.37)$ & $+2(0.51)$ & $+1(0.54)$ & & & & \\
\hline HOUZA & $+2(0.64)$ & $+1(0.56)$ & $+2(0.64)$ & $0(0.68)$ & $0(0.61)$ & & & \\
\hline SHIMAKATSU & $+2(0.55)$ & $+2(0.48)$ & $+1(0.49)$ & $+1(0.52)$ & $+1(0.49)$ & $0(0.68)$ & & \\
\hline KUKI-1 & $+3(0.40)$ & $+3(0.39)$ & $+1(0.41)$ & $+2(0.56)$ & $+1(0.42)$ & $+1(0.50)$ & $+1(0.64)$ & \\
\hline HAIDA & $+1(0.40)$ & $0(0.50)$ & $0(0.48)$ & $-3(0.54)$ & $-5(0.52)$ & $0(0.53)$ & $-2(0.53)$ & $-5(0.55)$ \\
\hline
\end{tabular}

Numerals in parenthesis and integers indicate coefficients and time-lags in day, respectively. Stations in upper panel lead those in left column. 
measurements for a statistical analysis, the temperature data at Shijima, Katada, Wagu, Aso, Nie, Houza, Shimakatsu, Kuki-1, and Haida were used for the analysis. The correlation coefficients and the time-lags indicate that the coastal area can be divided into a northern area (Shijima, Katada, and Wagu), a middle area (Aso, Nie, Houza, Shimakatsu, and Kuki-1), and a southern area (Haida). The stations in the northern and middle areas show that the temperatures fluctuate similataneously and are closely correlated. The time-lags in each area zero to one day, except for the 2-day time-lag between Aso and Kuki-1 due to the long distance between them. However, the table also shows that the fluctuations in the northern and southern areas lead those in the middle area with 2-3 day and 2-5 day time-lags, respectively, except for between Houza and Haida. This classification is similar to a classification based on the topography in which the middle area is much more
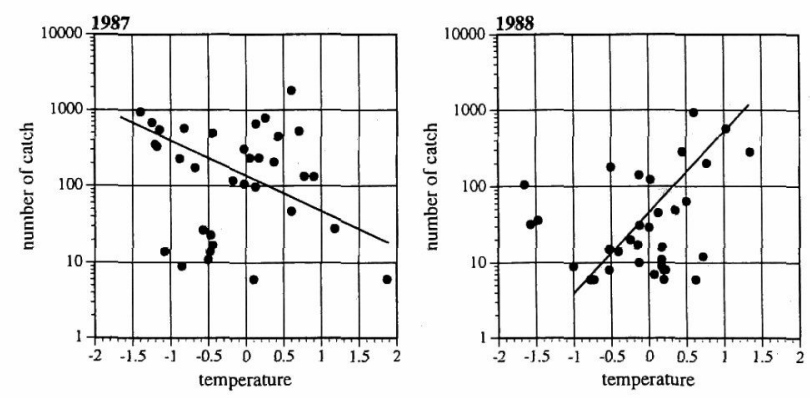

Fig. 5. Relationship between the offshore water temperature between $136.5^{\circ} \mathrm{E}$ and $137^{\circ} \mathrm{E}$ on the cruise line and the total catch of buri at the set net stations.

Solid lines indicate approximate trends. indented than the other two areas, and so the topographic effect is likely to be significant. Catches in the stations are thus totaled for the northern, middle, and southern areas: stations north of Wagu (2 stations), stations between Aso and Kuki-1 (4 stations, including one station located slightly south of Kuki-1), and stations south of Haida (3 stations), respectively.

Figure 4 shows large catches corresponding to the perodic warm water intrusions about every 50 days from the south of the Izu Peninsula. The time-lags between intrusion into the Kumano-nada Sea and catch are typically several weeks. The lengths of the time-lags vary in each case; those in the southern area are slightly longer than those in the northern area, although the catch variations in the three area are generally closely correlated with each. Therefore, the time of large catches does not always correspond to a high

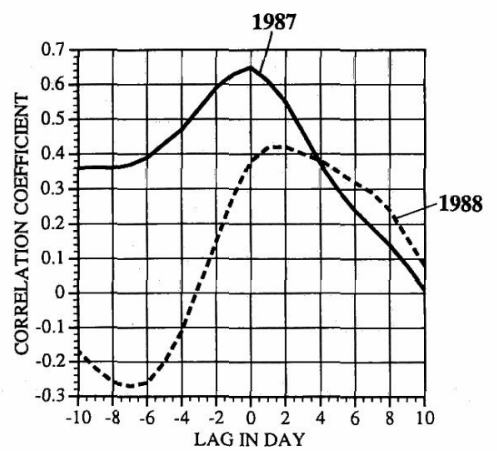

Fig. 6. Cross correlation functions and time-lag between offshore and coastal temperatures

Solid and broken lines indicate 1987 and 1988, respectively.

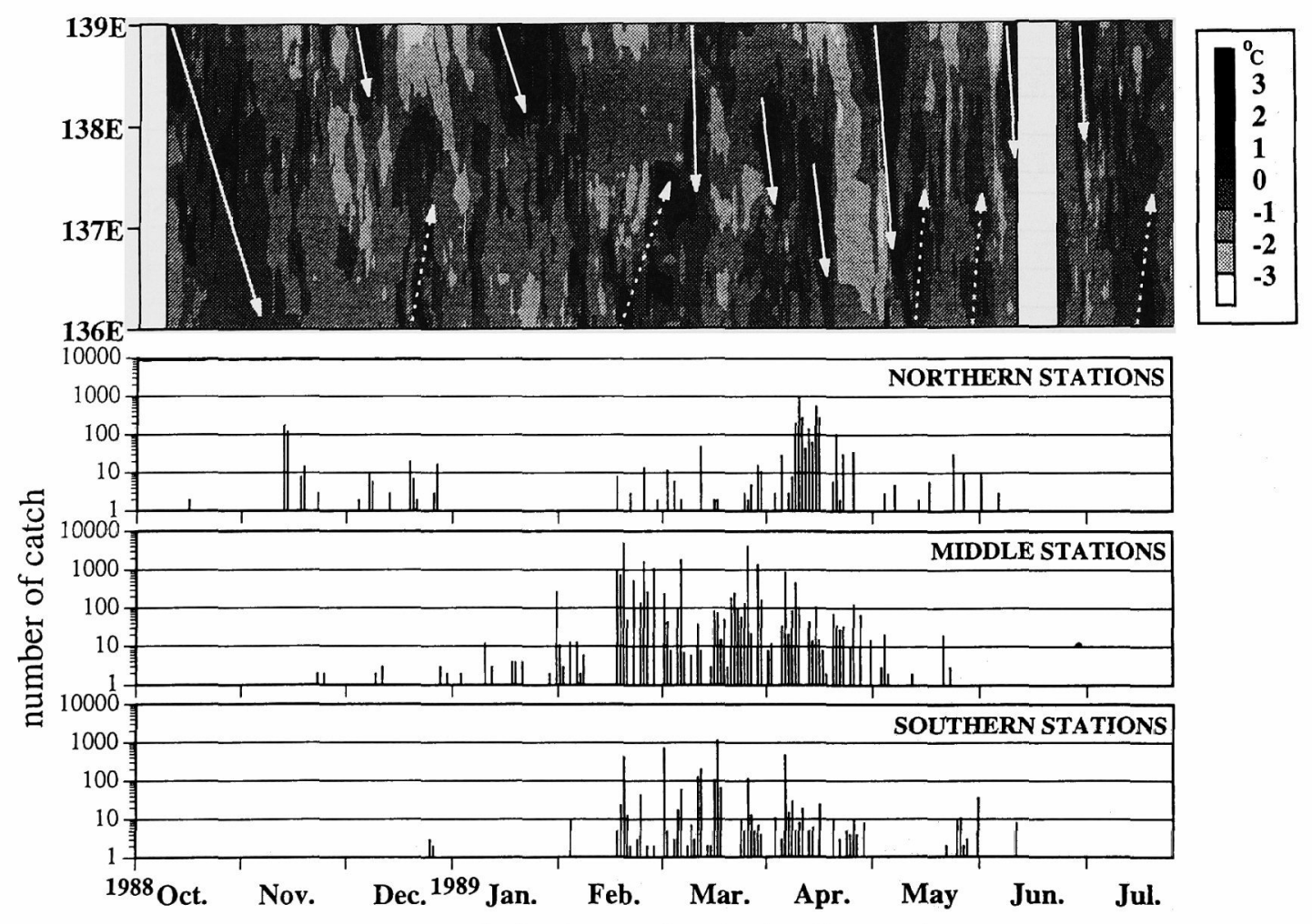

Fig. 7. Same as Fig. 4, but for 1988. 
offshore SST between $136.5^{\circ} \mathrm{E}$ and $137^{\circ} \mathrm{E}$. If anything, large catches at the set net stations lag behind the large warm water intrusion, although the timings are roughly the same.

Figure 5 shows the relationship between the offshore SST from $136.5^{\circ} \mathrm{E}$ to $137^{\circ} \mathrm{E}$ on the cruise line and the total catch of yellowtail in the northern area in 1987 and 1988. Compairing the catch with the offshore SST is desirable when considering the effect of warm water intrusion on yellowtail migration since yellowtail usually migrate to the offshore region. This figure shows how the catch decreased as the temperature increased in 1987, assuming that the smaller catch at $-0.5^{\circ} \mathrm{C}$ compared with this year's average is negligible. This implies that offshore SST has already descended when the fish schools migrate to the Kumanonada Sea. Therefore, the large warm water intrusions seem to negatively influence the catches as shown by the reverse trend in this case.

Figure 6 shows the cross-correlation coefficient and time-lag between the offshore SST from $136.5^{\circ} \mathrm{E}$ to $137^{\circ} \mathrm{E}$ and coastal SST with seasonal variations removed. The figure confirms that offshore oceanographic fluctuations influenced coastal oceanographic fluctuations without a time-lag in 1987, as in Fig. 2. Therefore, coastal SST, even regionally analyzed offshore SST, can not describe or forecast fish behavior or catch. Large-scale spatial analysis as shown in Fig. 4 is necessary to clarify the behavior.

In 1988 when the Kuroshio took the C-type path, the offshore SST showed no large intrusions from the south of the Izu Peninsula into the Kumano-nada Sea other than into the eastern part of the Enshu-nada Sea. The time -space diagram of offshore SST in 1988 shown in Fig. 7 confirms this. Warm water masses separated from the Kuroshio at the eastern region of the Izu Ridge could intrude only as far as the eastern region of the Enshu-nada Sea, which would be diffused before reaching the Kumano-nada Sea. However, several local small intrusions from the south of Cape Shionomisaki along the eastern coast of the Kii Peninsula and from the offshore area of the Enshu-nada
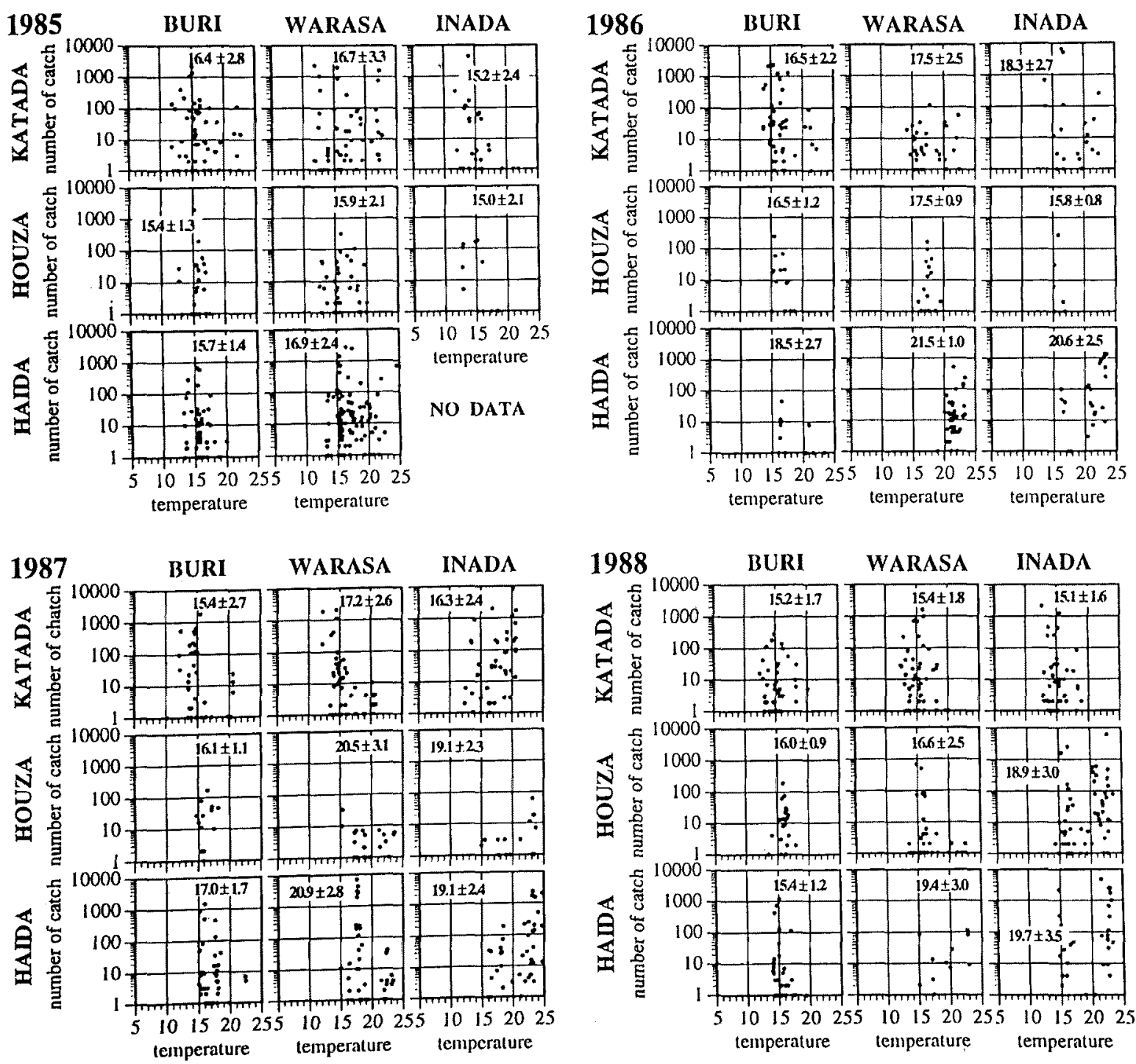

Fig. 8. Relationship between the coastal temperature and catches of buri, warasa, and inada at the three main set net stations. Numerals are mean temperature and standard deviation. 
Sea were evident in 1988 . The intruding water mass moved faster and on a smaller scale than the intrusions from the south of the Izu Peninsula observed in 1987.

Although the catch is not always related to the intrusions, the relationship between the offshore SST and the catch in 1988 shown in Fig. 5 show how the catch increases with increase of temperature. However, the catches in the three areas are not closely correlated and appear to be independent. The correlation function in Fig. 6 shows the time-lag between the offshore and coastal oceanographic fluctuations in 1988, but the correlation is not so significant. Large catches do not appear to be related to the movement of large water masses from the Izu Peninsula, and that coastal SST is independent of offshore oceanographic changes other than several sudden intrusions from the Kuroshio in 1988. However, the small warm water intrusions from the Kuroshio rapidly affect fish migration in the offshore region and lead to large catches in the coastal region. The fish catches in both years vary exponentially with change in temperature, suggesting that a major oceanographic change has a larger effect on fish migration.

In contrast fish catches with relative temperature fluctuations caused by warm water intrusions from the Kuroshio, buri are clearly fished in a very narrow temperature band of $14-17^{\circ} \mathrm{C}$ along the coast of the Kumano-nada Sea. Figure 8 shows the relationships between the coastal SST and catches of buri, warasa, and inada at Katada, Houza, and Haida set net stations, which are the main stations of the three areas. Buri are caught in water at approximately $16^{\circ} \mathrm{C}$ with $2^{\circ} \mathrm{C}$ standard deviation which is within the optimum temperature range noted by $\mathrm{Uda}^{24)}$ and the temperatures in 1986 and 1987 when the Kuroshio took the B-type path are higher than in 1985 and 1988 when the Kuroshio took the C-type path. However, warasa, and inada are caught in water at approximately $18^{\circ} \mathrm{C}$ which is $2^{\circ} \mathrm{C}$ higher than that of buri. The catchable temperature range of warasa and inada is very wide, $15-21^{\circ} \mathrm{C}$, while that of buri is very narrow. Buri appear to migrate over a very large area and come to the Kumano-nada and Enshu-nada during a very specific season when the coastal temperature is about $16^{\circ} \mathrm{C}$, whereas warasa and inada migrate throughout the season.

We have shown that fish catches fluctate with large offshore oceanographic changes. The mean offshore SST is about $2^{\circ} \mathrm{C}$ higher than the mean coastal SST and is outside the range of coastal SST at which buri are caught. Buri does not therefore migrate to the optimum temperature range; instead, its migration is influenced by the relative temperature changes caused by large oceanographic phenomenon.

\section{Discussions and Conclusions}

We have shown how the migration of buri is related to intrusions of warm water from the Kuroshio. Figure 4 shows that the large water mass moves west from the south of the Izu Peninsula at velocities of $10-20 \mathrm{~cm} / \mathrm{s}$ (calculated from arrows shown in Fig. 4). This water mass leads to large catches of buri in the coastal areas at intervals of 30-50 days and the large catches continue for at least three weeks. This period corresponds to the large water intrusion from the south of the Izu Peninsula. ${ }^{18,20)}$ However, fuctuations in offshore SST between $136.5^{\circ} \mathrm{E}$ and $137^{\circ} \mathrm{E}$ lead the variations in the buri catches even if the coastal SST increases with the offshore SST simultaneously. One possible hypothesis to explain the time-lag is that the buri school does not migrate westward over the Izu Ridge when the water mass intrudes from the south of the Izu Peninsula, since the water mass acts as a cap which prevents the buri school from its westward migration. The buri school migrates to the coasts of the Kumano-nada Sea after the water mass has diffused. This refutes the claim that, large fish catches are caused by a high density of fish between the Kuroshio and the coast.

The relationship between offshore SST and buri catch shows that the catch increases with temperature. The path of the Kuroshio is known to fluctuate with a period of 20 days where the associated frontal disturbances cause warm water intrusions into the coastal area of the Kumano-nada Sea. ${ }^{19)}$ This 20 -day cycle is accompanied by large buri catches in the set net stations of the Kumano-nada Sea and there is no time-lag between the variation of temperature and catch. ${ }^{7)}$ In 1988 , there were few large warm water intrusions, but there were many small intrusions recognized also in 1987 as described by Kimura and Sugimoto ${ }^{18}$ and Kasai et al. ${ }^{20)}$ The short periodic fluctuations of 20 days thus seem to have a positive effect as shown in Fig. 5 . The time and scale of the warm water mass with periods of 20 days which usually forms a streamer are considerably smaller than the mass with period of 50 days which usually forms an eddy. The offshore SST did not directly influence the coastal SST in 1988 while the warm water mass with the period of 20 days intruded faster than the mass with period of 50 days.

The effects seem to greatly depend on the scale of the intrusions because the streamer has local effects while the eddy intruding from the south of the Izu Peninsula affects the whole coastal area of the Kumano-nada Sea almost simultanously. The water intrusion with 20 -day period associated with the frontal distrubance serves to stop the westward migration of the buri school from the Kumano-nada Sea to the west of Cape Shinomisaki. Since the intrusion is downstream of the migration, it easily stops the migration and leads to large catches in the coastal area of the Kumano-nada Sea at the same time. The scale and location of the intruding water mass and the buri school changes in response to changing oceanographic conditions thus need to be studied further, although it will take many years. When predicting fish behavior in relation to oceanographic changes represented by temperature, it is very important to study the oceanic phenomena carefully and to analyze the characteristics.

We have shown how the buri school migrates in relation to the temperature distribution. In fact, buri are caught in a very narrow temperature range zone within $14-17^{\circ} \mathrm{C}$ as noted by $\mathrm{Uda}^{24)}$ However, buri respond to temperature both positively and negatively in the temperature band. Figure 9 shows average seasonal variations of the $17^{\circ} \mathrm{C}$ contour on the sea surface from 1906 to 1987 based on data from the Japan Oceanographic Data Center. The contour fluctuates from latitude $37^{\circ} \mathrm{N}$ to $43^{\circ} \mathrm{N}$ from May to December, while the temperature from January to April when the buri school migrates is almost the same on the Kumano-nada and Enshu-nada Seas between the Kuroshio 


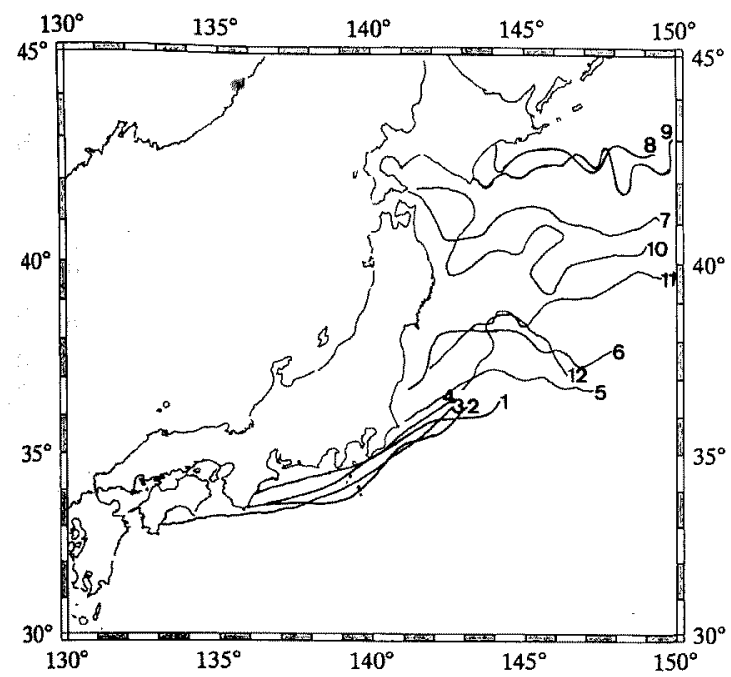

Fig. 9. Seasonal variations of $17^{\circ} \mathrm{C}$ contour on the sea surface averaged for 1906 to 1987.

Numerals are the months.

and the coast. The optimum temperature range for buri is estimated to be $14-17^{\circ} \mathrm{C}$, but, buri which have migrated to the Kumano-nada and Enshu-nada Seas migrate northward for feeding in summer and autumn. On the Sanriku coast, buri are caught at set net stations from June to December, yet $14-17^{\circ} \mathrm{C}$ water exists in the area only briefly. Therefore, most buri are actually caught outside of the $14-17^{\circ} \mathrm{C}$ optimum temperature range even if yellowtail migrate vertically seeking the optimum temperature in the coastal area during the stratification period. This reveals an inconsistency; the buri school migrates in the northern part of the Pacific Ocean regardless of temperature, while the migration is influenced by intrusions of warm water mass on the Kumano-nada and Enshu-nada Seas. The seasonal migration of buri may therefore not be related to temperature. In particular, when the seasonal horizontal temperature gradient is quite large in a fish-migration area, the temperature distribution should be analyzed carefully.

Usually, temperature is used to understand fish behavior because temperature can easily be used to distinguish water mass. However, the theory of an optimum temperature range can not always adequately explain fish behavior and the response of fish to temperature is quite different depending on the oceanographic phenomena. Thus, fish behavior must be analyzed in terms of something other than temperature.

\section{References}

1) Y. Ogawa: Variations of the Kuroshio's path and coastal fishing conditions on the southern region of Japan. Bull. Japan. Soc. Fish. Oceanogr., 18, 157-164 (1971).

2) M. Miki and T. Ikeda: Fishing conditions at large set net stations in and after appearances of the large cold water mass. Technical Report of Fisheries Research Institure of Mie, 18-24 (1975).

3) $T$. Iwasaki: Study on the fishing condition of yellowfin and skipjack purse seine in the Kinan and Izu regions. Bull. Japan. Soc. Fish. Oceanogr., 32, 27-33 (1978).

4) Y. Iwasaki: Relationship between the purse seine fishing conditions of bluefin tuna and yellowfin tuna and fluctuations of sea condition in the Kinan and Izu regions, Pacific Coast of Japan. Bull. Japan. Soc. Fish. Oceanogr., 45, 3-9 (1984).

5) N. Ito: Examples of variations of fishing conditions in relation to the variations of the Kuroshio's path. Technical Report of Fisheries Research Institute of Mie, 143-145 (1981).

6) Y. Ogawa and K. Wakabayashi: Changes in hydrographic conditions in relation to the Kuroshio meander and their influence on fishery resources. Bull. Natl. Res. Inst. Fish. Sci., 4, 71-89 (1992).

7) S. Kimura and T. Sugimoto: Short period fluctuations in oceanographic and fishing conditions in the coastal area of Kumanonada Sea. Nippon Suisan Gakkaishi, 53, 585-593 (1987).

8) K. Hamaguchi: Relationships between the buri fishing condition and the oceanographic condition on the Kumano-nada Sea. Mar. Sci., 19, $440-446$ (1987).

9) A. Nishimura: Oceanographic conditions on the Kumano-nada Sea on the basis of satellite imagery. Mar. Sci., 19, 434440 (1987).

10) J. Takeuchi: Warm water tongue and coastal upwelling on the southern part of the Kumano-nada Sea. Mar. Sci, 19, 447-455 (1987).

11) M. Kawabe: Sea level variations at the Izu Islands and typical stable paths of the Kuroshio. J. oceanogr. Soc. Japan, 41, 307-326 (1985).

12) M. Kawabe: Transition processes between the three typical paths of the Kuroshio. J. oceanogr. Soc. Japan, 42, 174191 (1986).

13) T. Sugimoto, J. Sasaki, and M. Kobayashi: Oceanic structure and variation on the Kumano-nada and Enshu-nada Seas. Bull. Japan Soc. Fish. Oceanogr., 49, 33-37 (1985).

14) J. Takeuchi: Warm water intrusion in the southern area of Kumano-nada. Bull. Japan Soc. Fish. Oceanogr, 53, 242-254(1989).

15) R. Kumabe and M. Hirota: Appearance of small warm water mass around a cold water mass off Tohkaido, Report of investigation for utilization and development of the Kuroshio, 7, 65-72 (1984).

16) K. Matsumoto: Situations of meander of the Kuroshio's path and inside countercurrent of the Kuroshio. Bull. Japan Soc. Fish. Oceanogr., 49, 52-54 (1985).

17) S. Kimura and T. Sugimoto: Characteristics of short period fluctuations in oceanographic and fishing conditions in the coastal area of Enshu-nade Sea. Bull. Japan Soc. Fish. Oceanogr., 52, 221-228 (1988).

18) S. Kimura and T. Sugimoto: Intrusion processes of warm water mass from the Kuroshio into the coastal area of Kumano-nada and Enshu-nada Sea. Bull. Japan Soc. Fish. Oceanogr., 54, 19-31 (1990).

19) S. Kimura and T. Suigimoto: Short-period fluctuations in meander of the Kuroshio's path off Cape Shionomisaki. J. geophys. Res., 98 , 2407-2418 (1993).

20) A. Kasai, S. Kimura, and T. Sugimoto: Warm water intrusion from the Kuroshio into the coastal areas south of Japan. $J$. Oceanogr. Soc. Japan, 49, 607-624 (1993)

21) S. Tanaka: Migration of yellowtails along the Pacific coast of Japan observed by tagging experiments-I. Results from release and recapture data. Nippon Suisan Gakkaishi, 38, 29-32 (1972).

22) S. Tanaka: Migration of yellowtails along the Pacific coast of Japan observed by tagging experiments-II. Consideration from catch statistics and length composition. Nippon Suisan Gakkaishi, 38 , 93-96 (1972).

23) A. Nishimura: Coastal oceanographic conditions and fish migration in the Kumano-nada Sea. Technical Report of Fisheries Research Institute of Mie, 36-43 (1991).

24) M. Uda: Fisheries oceanography, Fisheries Series 16, Kouseisha Kouseikaku, Tokyo, 1960, pp. 1-347.

25) Fisheries Research Institute of Mie: Statistics of Buri Catch at Set Net Station in Mie Prefecture in 1985, 1-42 (1987).

26) Fisheries Research Institute of Mie: Statistics of Buri Catch at Set Net Station in Mie Prefecture in 1986, 1-27 (1988).

27) Fisheries Research Institute of Mie: Statistics of Buri Catch at Set Net Station in Mie Prefecture in 1987, 1-31 (1989).

28) Fisheries Research Institute of Mie: Statistics of Buri Catch at Set Net Station in Mie Prefecture in 1988, 1-31 (1990).

29) M. Fujimoto and A. Tomosada: Mean temperature distribution southeast of Honshu, Japan, in view of the Kuroshio with and without meander. Bull. Tokai reg. Fish. Res. Lab., 103, 17-30 (1980). 